\title{
Mikroelem-terhelés hatása a céklára karbonátos csernozjom talajon
}

\author{
${ }^{1}$ KÁDÁR IMRE, ${ }^{1}$ KONCZ JÓZSEF és ${ }^{2}$ RADICS LÁSZLÓ \\ ${ }^{1}$ MTA Talajtani és Agrokémiai Kutatóintézet, Budapest és \\ ${ }^{2}$ Szent István Egyetem Kertészettudományi Kar, Budapest
}

A cékla vetésterülete mindössze $300-400$ ha hazánkban. Táplálkozási jelentőségét, mint zöldségnövénynek, gyökerének vitamin- (B-, C-, P-), ásványi sóés cukortartalma (6-9\%) adja. Megemlíthető, hogy a takarmányrépa, cukorrépa, mangold és a cékla egyetlen faj, a Beta vulgaris termesztett változata. Ösalakjuk feltehetően a Beta maritima vadon termő egyéves libatopféle, mely egyaránt megtalálható a Földközi-tenger és a Fekete-tenger partvidékén, a Nílus, valamint a Tigris és Eufrátesz folyók menti sós talajokon.

A répafélék, ill. a cékla karógyökere 1-2 m-re is lehatol, így jól képes hasznosítani a talaj víz- és tápelemkészletét. Ebből adódóan víz- és tápelemigénye közepesnek minősül. SZABÓ (1994) szerint a 10 t betakarításkori friss gyökér + a hozzá tartozó lomb fajlagos elemigénye $24 \mathrm{~kg} \mathrm{~N}, 14 \mathrm{~kg} \mathrm{P}_{2} \mathrm{O}_{5}, 60 \mathrm{~kg} \mathrm{~K} 2 \mathrm{O}$. Kiemelkedő tehát $\mathrm{K}$-igénye. A nagyobb termésekkel az egy ha-ról felvett elemek

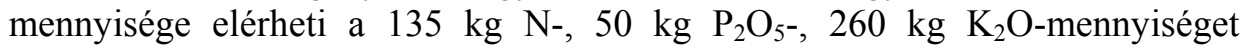
(FILIUS, 1994). A cékla optimális tápláltsági állapotának jellemzésére az alábbi határkoncentrációkat javasolják a lomb középtájáról vett, éppen kifejlett levél összetétele alapján: 3-5 \% N, 2,8-5\% K, 1,5-2,5\% Ca, 0,3-0,8 \% Mg, 0,250,50 \% P, 50-120 mg Mn, 35-80 mg B, 20-60 mg Zn, 7-15 mg Cu, 0,2-1,0 mg Mo/kg szárazanyag (BERGMANN, 1988).

A zöldségfélék vegetatív részeit fogyasztjuk, ezért különösen fontos megismerni elemfelvételüket szennyezett/terhelt talajon. Az ez irányú hazai kutatások is kiszélesedtek, egyre több közlemény foglalkozik a talaj-növény rendszer nitrát-, nehézfém- és egyéb károselem-forgalmával (CSATHÓ, 1994; FILEP, 1988; LOCH, 1992 VERMES, 1994 SiMON, 1998; NÉMETH et al., 1993). A saláta, hagyma és a kukorica elemdúsulásait pl. savanyú és meszezett talajon is elemzik tenyészedény-kísérleteikben LEHOCZKY és munkatársai (1988, 1998, 1998a, 1996). Céklával tudomásunk szerint ilyen kísérletek nem folytak még hazánkban, így a továbbiakban ez irányú eredményeinket mutatjuk be. 


\section{Anyag és módszer}

Kísérletünket 1991 tavaszán állítottuk be az MTA TAKI Nagyhörcsöki Kísérleti Telepén. A termőhely löszön képződött mészlepedékes csernozjom talaja a szántott rétegben átlagosan $5 \% \mathrm{CaCO}_{3}$-ot és $3 \%$ humuszt tartalmaz. Fizikai féleségét tekintve vályog, $20 \%$ agyag, ill. $40 \%$ leiszapolható rész frakcióval. Agyagásványainak közel felét illit, 1/3-át klorit, kisebb részét szmektit alkotja. A talajvíz tükre kb. $15 \mathrm{~m}$ mélyen helyezkedik el, szennyeződése felszíni kilúgozással gyakorlatilag kizárt. A telep éghajlata az Alföldéhez hasonlóan száraz, aszályra hajló. Szántott rétegében a $\mathrm{pH}(\mathrm{KCl}) 7,3, \mathrm{AL}_{-} \mathrm{P}_{2} \mathrm{O}_{5^{-}} 80-100$, AL- $\mathrm{K}_{2} \mathrm{O}-140-160$, KCl-Mg- 150-180, a KCl+EDTA-oldható Mn- 80-150, Cu2-3, Zn-tartalom 1-2 mg/kg értéket mutat. A MÉM NAK (1979) által bevezetett módszerek és határértékek alapján ezek az adatok a talaj igen jó Mn-, kielégítő $\mathrm{Mg}$ - és $\mathrm{Cu}$-, közepes N- és K-, valamint gyenge P- és Zn-ellátottságáról tanúskodnak.

Az alkalmazott kezelések olyan talajszennyezettségi viszonyokat modelleznek, melyek ipari létesítmények, autóutak és települések szennyezett környezetében, városi kiskertekben ma is előfordulnak vagy a jövőben előfordulhatnak. A 13 vizsgált mikroelem sóját 4-4 szinten egyszer alkalmaztuk 1991 tavaszán, az első évben vetett kukorica alá. A 13 x $4=52$ kezelést 2 ismétlésben állítottuk be összesen 104 parcellán, split-plot elrendezésben. A terhelési szintek $0,90,270,810 \mathrm{~kg} /$ ha mennyiséget jelentettek elemenként $\mathrm{AlCl}_{3}, \mathrm{NaAsO}_{2}$, $\mathrm{BaCl}_{2}, \mathrm{CdSO}_{4}, \mathrm{~K}_{2} \mathrm{CrO}_{4}, \mathrm{CuSO}_{4}, \mathrm{HgCl}_{2},\left(\mathrm{NH}_{4}\right)_{6} \mathrm{Mo}_{7} \mathrm{O}_{24}, \mathrm{NiSO}_{4}, \mathrm{~Pb}\left(\mathrm{NO}_{3}\right)_{2}$, $\mathrm{Na}_{2} \mathrm{SeO}_{3}, \mathrm{SrSO}_{4}, \mathrm{ZnSO}_{4}$ formájában. Az alaptrágyázást évente végeztük 100 100-100 kg/ha N, $\mathrm{P}_{2} \mathrm{O}_{5}$ és $\mathrm{K}_{2} \mathrm{O}$ hatóanyag alkalmazásával ammonnitrát-, szuperfoszfát- és kálisó-mütrágyákkal.

A kísérletben végzett mủveletekről és megfigyelésekről az 1. táblázat nyújt áttekintést. A vetés április 25-én történt Detroit Standard fajtával, Nibex szemenkénti vetőgéppel, $2-3 \mathrm{~cm}$ mélyre helyezve a monogerm magvakat. A választott fajta friss fogyasztásra és konzervipari feldolgozásra egyaránt alkalmas. Gyökértermése 10-25 t/ha között ingadozik, de öntözve 2-3-szoros mennyiségre is képes. A sor x tő távolságot többszöri egyelést követően $50 \times 10 \mathrm{~cm}$-re állítottuk be, mely 200 ezer db/ha tőszámot jelent.

Bonitálást végeztünk állományfejlettségre május végén 2-4 leveles korban és betakarítás előtt (1-5 skálán). Levélanalízis céljából parcellánként 20-20 növény föld feletti hajtását gyüjtöttük a tenyészidő közepén, június 21-én. Betakarításkor (szeptember 8-án) 20-20 leveles gyökeret vettünk parcellánként a laboratóriumi vizsgálatokra. Megmértük az átlagminták friss és légszáraz tömegét (40-50 ${ }^{\circ} \mathrm{C}$-on történt szárítást követően), majd a $300 \mathrm{db}$ átlagmintát finomra daráltuk és $\mathrm{cc} . \mathrm{HNO}_{3}+\mathrm{cc} \cdot \mathrm{H}_{2} \mathrm{O}_{2}$ roncsolás után 20-24 elemre analizáltuk, ICPtechnikát alkalmazva. 


\section{1. táblázat}

A kísérletben végzett múveletek és megyfigyelések, 1995 (Karbonátos csernozjom talaj, Nagyhörcsök)

\begin{tabular}{|c|c|c|}
\hline $\begin{array}{c}\text { (1) } \\
\text { Múveletek megnevezése }\end{array}$ & $\begin{array}{c}\text { (2) } \\
\text { Idôpontja } \\
\text { (év, hónap, nap) }\end{array}$ & $\stackrel{(3)}{\text { Megjegyzés }}$ \\
\hline 1. Öszi NPK-mütrágyázás & 1994. 10. 21. & Parcellánként kézzel szórva \\
\hline 2. Egyirányú szántás & 1994. 10. 21. & MTZ-80 + Lajta eke \\
\hline 3. Fogasolás & 1995. 04. 06. & MTZ-80 + fogas \\
\hline 4. Tavaszi N-mütrágyázás & 1995.04 .06$. & Parcellánként kézzel \\
\hline 5. Kombinátorozás & 1995.04 .06$. & MTZ-80 + kombinátor \\
\hline 6. Vetés, hengerezés & 1995. 04. 25. & Szemenként vetőgéppel \\
\hline 7. Kísérlet karózása & 1995.05 .15$. & Parcellánként kézzel \\
\hline 8. Bonitálás gyomosságra & 1995.05 .24$. & Parcellánként 1-5 skálán \\
\hline 9. Bonitálás fejlettségre & 1995.05 .29$. & Parcellánként 1-5 skálán \\
\hline 10. Kapáló gyomirtás & 1995.05 .31$. & Az egész kísérletben \\
\hline 11. Kapáló gyomirtás & 1995.06 .14$. & Az egész kísérletben \\
\hline 12. Növénymintavétel & 1995. 06. 21. & 20 hajtás parcellánként \\
\hline 13. Tőszámbeállítás & 1995. 06. 27. & Parcellánként kézzel \\
\hline 14. Növénymintavétel & 1995.09 .08$. & 20 db leveles gyökér parcellánként \\
\hline 15. Bonitálás fejlettségre & 1995. 09. 11. & Parcellánként 1-5 skálán \\
\hline 16. Betakarítás & 1995. 09. 11. & Parcellánként 24-24fm \\
\hline
\end{tabular}

A parcellák bruttó területe $3,5 \times 6=21 \mathrm{~m}^{2}$. Betakarításkor a belső $4-4$ sor állományát emeltük ki, tehát a nettó értékelt terület $6 \times 4=24 \mathrm{fm}$, azaz $12 \mathrm{~m}^{2}-\mathrm{t}$ tett ki. Talajmintavételre, ill. talajvizsgálatokra 1994. évben került sor. Ekkor parcellánként 20-20 pontminta egyesítésével átlagmintákat képeztünk a szántott rétegből és meghatároztuk az „összes” készletet cc. $\mathrm{HNO}_{3}+\mathrm{cc} . \mathrm{H}_{2} \mathrm{O}_{2}$ roncsolásból, ill. a „könnyen oldható” tartalmakat $\mathrm{NH}_{4}$-acetát + EDTA kioldásból LAKANEN és ERVIÖ (1971) szerint. A kísérlet első évében kukoricát, a 2. évben sárgarépát, a 3. évben burgonyát, a 4. évben borsót termesztettünk. A kísérlet célját, módszerét, valamint a megelőző évek föbb eredményeit korábbi közleményeink foglalják össze (KÁDÁR et al., 2000, 2000a; KÁDÁR \& PROKISCH, 2000; KÁDÁR, 2001).

A termőhely csapadékadatait az 1991-1994. évek időszakára korábbi közleményünk tartalmazza (KÁDÁR et al., 2000). Az 1995-2000. évek havi, negyedéves, éves és a fö tenyészidőre vetített csapadékösszegek eredményeit a 2. táblázatban foglaltuk össze. Az 1995. évben 107 mm-rel kevesebb csapadék hullott, mint a sokéves átlag. Augusztusban a cékla mindössze $7 \mathrm{~mm}$ csapadékot kapott, így a termés is mérsékelt maradt. A száraz, forró július és augusztus nem kedvezett a cékla fejlödésének. 


\section{2. táblázat}

A havi, negyedéves, éves és a tenyészidő alatti csapadékösszegek adatai, mm (Karbonátos csernozjom talaj, Nagyhörcsök, 1995-2000)

\begin{tabular}{|l|r|r|r|r|r|r|r|}
\hline \multicolumn{1}{|c|}{$\begin{array}{c}\text { Hónapok } \\
\text { a) január }\end{array}$} & $\mathbf{1 9 9 5}$ & $\mathbf{1 9 9 6}$ & $\mathbf{1 9 9 7}$ & $\mathbf{1 9 9 8}$ & $\mathbf{1 9 9 9}$ & $\mathbf{2 0 0 0}$ & $\begin{array}{c}\text { (2) } \\
\text { Atlag* }\end{array}$ \\
b) február & 12 & 4 & 0 & 54 & 15 & 31 & 34 \\
c) március & 53 & 15 & 8 & 0 & 44 & 19 & 36 \\
d) április & 33 & 3 & 13 & 28 & 17 & 32 & 37 \\
e) május & 38 & 11 & 8 & 104 & 87 & 53 & 48 \\
f) június & 89 & 41 & 60 & 36 & 192 & 10 & 61 \\
g) július & 30 & 15 & 50 & 63 & 129 & 44 & 54 \\
h) augusztus & 7 & 25 & 8 & 61 & 60 & 11 & 55 \\
i) Szeptember & 87 & 160 & 4 & 114 & 19 & 43 & 49 \\
j) október & 7 & 0 & 37 & 73 & 53 & 32 & 53 \\
k) november & 22 & 28 & 28 & 48 & 95 & 34 & 57 \\
l) december & 68 & 42 & 51 & 22 & 42 & 57 & 42 \\
m) I. negyedév & 98 & 22 & 21 & 82 & 76 & 82 & 107 \\
n) II. negyedév & 164 & 115 & 120 & 220 & 356 & 82 & 173 \\
o) III. negyedév & 124 & 201 & 63 & 239 & 208 & 98 & 158 \\
p) IV. negyedév & 98 & 69 & 115 & 142 & 190 & 122 & 152 \\
r) Éves összeg & 483 & 407 & 319 & 682 & 830 & 384 & 590 \\
s) IV-IX. havi & 287 & 316 & 183 & 458 & 564 & 180 & 331 \\
t) X-VI. havi & 329 & 234 & 211 & 417 & 574 & 355 & 432 \\
\hline
\end{tabular}

* Sokéves átlag a legközelebbi állomás, Sárbogárd 50 éves átlaga

\section{Kísérleti eredmények}

\section{Mikroelem-terhelés hatása a talajra 1994-ben}

Az „összes” tartalmakat kémiai módszerekkel, általában tömény savakkal becsüljük. Kérdés, hogy a talajba került szennyezés mennyire mutatható ki kémiai eljárásainkkal, mekkora a visszamérés \%-a? Minderre konkrét választ csak a terhelési kísérletekben kaphatunk. A könnyen oldható tartalmakat, ill. határkoncentrációkat ugyancsak kísérletesen lehet megállapítani eltérő talajokon és növénykultúrákban. A növények reakciója, károsanyag-felvétele fajonként változó. E téren a hazai vizsgálatok alapvető fontosságúak a mobilis szennyezettségi kritikus koncentrációk megismerésében, melyeket a talajhasználati céloktól függően differenciálva állapíthatunk meg. 
A visszanyerési/visszamérési \%-ok megállapításánál abból indultunk ki, hogy a $\mathrm{kb} .20 \mathrm{~cm}$ szántott talajréteg (1,5 átlagos térfogattömeggel számolva) hektáronként mintegy 3 millió $\mathrm{kg}$ tömeget jelent, azaz $3 \mathrm{~kg} / \mathrm{ha}$ terhelés $1 \mathrm{mg} / \mathrm{kg}$ mennyiségnek felel meg. Ebben a kísérletben $0,90,270,810 \mathrm{~kg} / \mathrm{ha}$ terhelést/ adagokat alkalmaztunk elemenként, mely 0,30, 90 ill. $270 \mathrm{mg} / \mathrm{kg}$ talajszennyezést jelent.

\section{3. táblázat}

Kezelések hatása a szántott réteg összetételére, $\mathrm{mg} / \mathrm{kg}$ (Karbonátos csernozjom talaj, Nagyhörcsök)

\begin{tabular}{|c|c|c|c|c|c|c|}
\hline \multirow{2}{*}{$\begin{array}{c}(1) \\
\text { Elem }\end{array}$} & \multicolumn{4}{|c|}{ (2) Terhelés 1991 tavaszán, kg/ha } & \multirow{2}{*}{$\begin{array}{c}(3) \\
\mathbf{S z D}_{\mathbf{5} \%}\end{array}$} & \multirow{2}{*}{ Átlag } \\
\hline & $\mathbf{0}$ & 90 & 270 & 810 & & \\
\hline \multicolumn{7}{|c|}{ A. cc. $\mathrm{HNO}_{3}+$ cc. $\mathrm{H}_{2} \mathrm{O}_{2}$ kioldás 1994-ben* } \\
\hline As & 7 & 28 & 81 & 210 & 34 & 86 \\
\hline $\mathrm{Ba}$ & 80 & 111 & 154 & 398 & 54 & 221 \\
\hline $\mathrm{Cd}$ & 0.3 & 18 & 50 & 162 & 18 & 62 \\
\hline $\mathrm{Cr}$ & 18 & 48 & 64 & 121 & 57 & 63 \\
\hline $\mathrm{Cu}$ & 17 & 43 & 85 & 230 & 24 & 120 \\
\hline $\mathrm{Hg}$ & 0 & 26 & 67 & 157 & 33 & 66 \\
\hline Mo & 0 & 10 & 20 & 114 & 24 & 36 \\
\hline $\mathrm{Ni}$ & 28 & 63 & 112 & 248 & 18 & 113 \\
\hline $\mathrm{Pb}$ & 10 & 49 & 142 & 264 & 33 & 117 \\
\hline $\mathrm{Se}$ & 7 & 29 & 81 & 224 & 22 & 88 \\
\hline $\mathrm{Sr}$ & 60 & 90 & 158 & 352 & 28 & 165 \\
\hline $\mathrm{Zn}$ & 40 & 71 & 118 & 274 & 26 & 127 \\
\hline \multicolumn{7}{|c|}{ B. $\mathrm{NH}_{4}$-acetát + EDTA kioldás 1994-ben** } \\
\hline As & 0 & 4 & 21 & 80 & 9 & 26 \\
\hline $\mathrm{Ba}$ & 18 & 27 & 40 & 67 & 16 & 38 \\
\hline $\mathrm{Cd}$ & 0 & 14 & 44 & 164 & 13 & 56 \\
\hline $\mathrm{Cr}$ & 0 & 1 & 2 & 4 & 1 & 2 \\
\hline $\mathrm{Cu}$ & 4 & 23 & 65 & 192 & 12 & 71 \\
\hline $\mathrm{Hg}$ & 0 & 2 & 12 & 41 & 2 & 14 \\
\hline Mo & 0 & 3 & 7 & 25 & 4 & 9 \\
\hline $\mathrm{Ni}$ & 4 & 22 & 48 & 86 & 9 & 40 \\
\hline $\mathrm{Pb}$ & 5 & 29 & 101 & 260 & 19 & 99 \\
\hline $\mathrm{Se}$ & 0 & 8 & 33 & 89 & 11 & 32 \\
\hline $\mathrm{Sr}$ & 40 & 57 & 99 & 314 & 32 & 118 \\
\hline $\mathrm{Zn}$ & 1 & 19 & 44 & 147 & 11 & 53 \\
\hline
\end{tabular}

* Hg és Mo 0,1 ppm körül, B 1, Co 8, Na 61, S 432, Mn 684, P 1127, K 1555, Mg 8446, Al 10796, Fe 15789 ppm átlagosan. ** As, Cd, Cr, Hg, Mo, Se 0,1 ppm körül, Co és B 2, Na és S 40, Al 67, Fe 71, P 100, K 266, Mn és Mg 400 ppm átlagosan 
Amint a 3. táblázat adataiból kitűnik, a szántott réteg elemtartalma az alumíniumot kivéve egy vagy több nagyságrenddel dúsult a terhelés nyomán. Ez a változás mind az „összes”, mind a mobilis vagy felvehető koncentrációkban nyomon követhető. Az alumínium esetén a terhelés egyáltalán nem mutatható ki egyik módszerrel sem. Az Al-szilikátok az egyik legfőbb talajalkotók, tömegükhöz képest elenyésző az Al-bevitel.

A visszamérési \%-ok elemenként és természetszerüen módszerenként eltérőek a táblázatokban közöltek alapján. Ami az „összes” tartalmakat illeti látható, hogy - a szórásokat figyelembe véve - az átlagos visszamérhetőségi sorrend az alábbi: $\mathrm{Pb}, \mathrm{Sr}, \mathrm{Ba}, \mathrm{Ni}, \mathrm{Zn}, \mathrm{Cu}, \mathrm{Se}, \mathrm{As}, \mathrm{Hg}, \mathrm{Cr}, \mathrm{Cd}, \mathrm{Mo}, \mathrm{Al}$. Azaz, a talajba jutott szennyező elemek közül 1994-ben (4 év után) a szántott rétegben kimutatható:

- Pb, Sr, Ba, Ni, Zn $90 \%$ felett,

- $\mathrm{Cu}, \mathrm{Se}, \mathrm{As}, \mathrm{Hg} 60-90$ \% között,

- Cr, Cd, Mo 30-60 \% között,

- Al $10 \%$ alatt.

A 3. táblázatban bemutatott könnyen oldható tartalmakat illetően, ugyanazon mintákban az átlagos visszamérési sorrend az alábbinak adódott: $\mathrm{Pb}, \mathrm{Sr}, \mathrm{Cu}$, $\mathrm{Zn}, \mathrm{Cd}, \mathrm{Ni}, \mathrm{Se}, \mathrm{Ba}, \mathrm{As}, \mathrm{Mo}, \mathrm{Hg}, \mathrm{Cr}, \mathrm{Al}$. Azaz a talajba jutott szennyező elemek közül 1994-ben (4 év után) a szántott rétegben kimutatható:

$-\mathrm{Pb} 90 \%$ felett,

- Sr 60-90 \% között,

- $\mathrm{Cu}, \mathrm{Zn}, \mathrm{Cd}, \mathrm{Ni}$, Se 30-60 \% között,

- Ba, As, Mo, Hg 10-30 \% között,

$-\mathrm{Cr}, \mathrm{Al} 10 \%$ alatt.

Figyelemre méltó, hogy az $\mathrm{Pb}$-szennyezés mindkét módszerrel jól jelezhető. A másik elem, amely esetében az „összes” és az oldható koncentrációk átlagai jól egyeznek a Cd, melynél a visszanyerési értékek 50-60 \% közöttinek adódtak. Az ólom és a kadmium két kulcsfontosságú környezetszennyező. Ezen elemek nyomon követésére elégséges csupán a felvehető koncentrációkat meghatározni ahhoz, hogy hasonló tulajdonságú talajokon egy szennyezést utólag minősítsünk, a terhelést számszerüen is kifejezzük. A minősítésnél figyelembe veendő a szennyezés kora vagy időtartama, mert a friss szennyezők általában jobban kimutathatók a mobilis frakciókban. Másrészről az adott sók oldhatósága eredendően sem azonos, ill. különböző módon alakulnak át a talajban, a talajösszetevőkkel kölcsönhatásba lépve. 
Mikroelem-terhelés hatása a cékla és a gyomok fejlödésére

A 4. táblázatban bemutatott adatok szerint négy elem okozott terméscsökkenést: As, $\mathrm{Cd}, \mathrm{Cr}$ és Se. A bonitálási eredmények arra utalnak, hogy az arzén által okozott mérgezés idővel mérséklődött, sőt a gyökér és a lombtermés sem jelezte már igazolhatóan betakarításkor. Ezzel szemben a króm depresszív hatása drasztikusan erősödött a korral, betakarítás idejére már a $810 \mathrm{~kg} / \mathrm{ha}$ terhelésü

4. táblázat

Terméscsökkenést okozó toxikus elemek hatása a céklára, 1995

(Karbonátos csernozjom, Nagyhörcsök)

\begin{tabular}{|c|c|c|c|c|c|c|}
\hline \multirow{2}{*}{$\begin{array}{c}(1) \\
\text { Elem }\end{array}$} & \multicolumn{4}{|c|}{ (2) Terhelés 1991 tavaszán, kg/ha } & \multirow{2}{*}{$\begin{array}{c}(3) \\
\mathbf{S z D}_{\mathbf{5} \%}\end{array}$} & \multirow{2}{*}{$\begin{array}{l}(4) \\
\text { Átlag }\end{array}$} \\
\hline & $\mathbf{0}$ & 90 & 270 & 810 & & \\
\hline \multicolumn{7}{|c|}{ A. Bonitálás fejlettségre máj. 29-én } \\
\hline As & 5,0 & 5,0 & 5,0 & 2,0 & & 4,3 \\
\hline $\mathrm{Cd}$ & 4,5 & 2,5 & 1,5 & 1,5 & 1,3 & 2,5 \\
\hline $\mathrm{Cr}$ & 4,5 & 4,5 & 4,0 & 3,5 & & 4,1 \\
\hline $\mathrm{Se}$ & 4,5 & 1,0 & 1,0 & 1,0 & & 1,9 \\
\hline \multicolumn{7}{|c|}{ B. Bonitálás fejlettségre szept. 11-én } \\
\hline As & 4,5 & 4,0 & 4,0 & 2,5 & & 3,8 \\
\hline $\mathrm{Cd}$ & 4,0 & 4,0 & 2,5 & 1,5 & 1,9 & 3,0 \\
\hline $\mathrm{Cr}$ & 4,5 & 4,0 & 4,0 & 1,5 & & 3,5 \\
\hline $\mathrm{Se}$ & 5,0 & 3,5 & 1,0 & 1,0 & & 2,6 \\
\hline \multicolumn{7}{|c|}{ C. Friss lombtömeg, g/20 növény jún. 21-én } \\
\hline As & 328 & 232 & 269 & 241 & & 268 \\
\hline $\mathrm{Cd}$ & 283 & 268 & 112 & 101 & 144 & 191 \\
\hline $\mathrm{Cr}$ & 314 & 318 & 259 & 221 & & 278 \\
\hline $\mathrm{Se}$ & 352 & 159 & 0 & 0 & & 128 \\
\hline \multicolumn{7}{|c|}{ D. Friss lombtömeg, t/ha szept. 11-én } \\
\hline As & 4,5 & 4,6 & 4,3 & 5,2 & & 4,6 \\
\hline $\mathrm{Cd}$ & 4,2 & 4,3 & 3,1 & 1,2 & 2,8 & 3,2 \\
\hline $\mathrm{Cr}$ & 6,0 & 4,7 & 6,3 & 2,0 & & 4,8 \\
\hline $\mathrm{Se}$ & 4,6 & 3,2 & 0,0 & 0,0 & & 2,0 \\
\hline \multicolumn{7}{|c|}{ E. Friss gyökértömeg, t/ha szept. 11-én } \\
\hline As & 14,7 & 17,1 & 17,6 & 12,3 & & 15,4 \\
\hline $\mathrm{Cd}$ & 16,2 & 12,9 & 5,3 & 1,5 & 8,7 & 9,0 \\
\hline $\mathrm{Cr}$ & 19,1 & 16,6 & 12,0 & 3,5 & & 12,8 \\
\hline $\mathrm{Se}$ & 16,7 & 11,4 & 0,0 & 0,0 & & 7,0 \\
\hline
\end{tabular}

Megjegyzés: Légszáraz anyag a lombban jún. 21-én $9 \%$; betakarításkor $18 \%$ (a gyökérben $14 \%$ átlagosan). Bonitálás: 1= igen gyenge, pusztuló állomány, 5= jól fejlett állomány 
parcellákon jórészt kipusztultak a növények. Korábbi vizsgálataink szerint a kromát formában adott $\mathrm{Cr}(\mathrm{VI})$ a szántott réteg alatt dúsult fel, míg az arzén a szántott rétegben maradt. Feltehető, hogy míg az arzénnal szennyezett réteget a cékla idővel kinőtte, addig a krómmal szennyezettbe „belenőtt”.

A növekvő Cd-terheléssel a növény tömege az egész tenyészidő folyamán alacsony maradt, különösen a betakarításkori gyökértermés csökkent drasztikusan (a kontrolltalajon mért érték 1/10-ére). A Se-toxicitás volt a leginkább kifejezett, mely a 270 , ill. $810 \mathrm{~kg} /$ ha kezelésben már a keléskori állomány elszáradásához, pusztulásához vezetett. A lomb légszáraz anyaga jún. 21-én $9 \%$-ot, szept. 6-án (betakarításkor) $18 \%$-ot tett ki. A betakarításkori gyökér átlagosan $14 \%$ légszáraz anyagot tartalmazott (4. táblázat).

\section{5. táblázat}

Terméscsökkenést okozó toxikus elemek hatása a cékla és a gyom fejlettségére, 1995. május 31. (Karbonátos csernozjom talaj, Nagyhörcsök)

\begin{tabular}{|c|c|c|c|c|c|c|}
\hline \multirow{2}{*}{$\begin{array}{c}(1) \\
\text { Elem }\end{array}$} & \multicolumn{4}{|c|}{ (2) Terhelés 1991 tavaszán, kg/ha } & \multirow{2}{*}{$\begin{array}{c}(3) \\
\mathbf{S z D}_{\mathbf{5} \%}\end{array}$} & \multirow{2}{*}{ Átlag } \\
\hline & $\mathbf{0}$ & 90 & 270 & 810 & & \\
\hline \multicolumn{7}{|c|}{ A. Céklafedettség \%-a } \\
\hline As & 3,5 & 4,5 & 5,0 & 3,0 & & 4,0 \\
\hline $\mathrm{Cd}$ & 4,0 & 3,0 & 2,2 & 1,8 & 2,9 & 2,7 \\
\hline $\mathrm{Cr}$ & 5,5 & 5,5 & 4,5 & 3,0 & & 4,6 \\
\hline $\mathrm{Se}$ & 4,5 & 1,3 & 0,0 & 0,0 & & 1,5 \\
\hline \multicolumn{7}{|c|}{ B. Gyomfedettség \%-a } \\
\hline As & 74 & 71 & 56 & 6 & & 52 \\
\hline $\mathrm{Cd}$ & 89 & 96 & 46 & 74 & 21 & 76 \\
\hline $\mathrm{Cr}$ & 85 & 89 & 73 & 30 & & 69 \\
\hline $\mathrm{Se}$ & 78 & 29 & 1 & 0 & & 27 \\
\hline \multicolumn{7}{|c|}{ C. Összes fedettség \%-a } \\
\hline As & 78 & 75 & 61 & 9 & & 56 \\
\hline $\mathrm{Cd}$ & 93 & 99 & 48 & 75 & 21 & 79 \\
\hline $\mathrm{Cr}$ & 91 & 94 & 78 & 33 & & 74 \\
\hline $\mathrm{Se}$ & 80 & 30 & 1 & 0 & & 28 \\
\hline \multicolumn{7}{|c|}{ D. Amaranthus blitoides fedettség $\%-a$} \\
\hline As & 53 & 55 & 52 & 0 & & 40 \\
\hline $\mathrm{Cd}$ & 88 & 95 & 45 & 73 & 24 & 75 \\
\hline $\mathrm{Cr}$ & 83 & 82 & 68 & 28 & & 65 \\
\hline $\mathrm{Se}$ & 70 & 28 & 1 & 0 & & 25 \\
\hline
\end{tabular}

Megjegyzés: A Chenopodium fajok 3-4 \% borítottsága mellett még 13 gyomfaj jelenléte volt azonosítható 
A cékla lassan indult fejlődésnek. Május végén a talajt mindössze 4-5\%-ban borította. A gyomborítottság viszont elérte a 80-90\%-ot a gyomirtó kapálás előtt. Domináns gyomfaj az Amaranthus blitoides volt. A Chenopodium fajok 3-4\%-os fedettségén túl még 13 gyomfajt azonosítottunk a kísérletben. Gyomokra a nagyobb As-, Cr- és fóként a Se-kezelés hasonlóképpen toxikus hatású volt, mint a céklára (5. táblázat).

A kísérletes gyombiológiai kutatások előtérbe kerülésével lehetővé válik a kultúrnövény és gyomok versengésének részletes megismerése és ezen keresztül a gyomszabályozás lehetőségének feltárása is. A tápanyagokért és a vízért folyó versengés mellett újabb területet jelenthet a gyomok és a főbb kultúrnövények talajszennyezőkkel szembeni érzékenysége. Kevésbé szennyezett talajokon felvetődhet a fitoremediáció, mint reális alternatíva. A kétszikü, nagytestü gyomfajokat ugyanis intenzív anyagcsere jellemzi és kimagasló mikroelem-felvételre képesek (KÁDÁR et al., 2000; LEHOCZKY et al., 1988; LEHOCZKY, 1994).

\section{Mikroelem-terhelés hatása a cékla elemösszetételére}

A kezelések hatását a légszáraz cékla összetételére a 6. táblázatban tanulmányozhatjuk. Az arzén mozgása szemmel láthatóan gátolt a talaj-növény rendszerben, az akkumuláció mérsékelt maradt. A 8/1985. (X. 21.) EüM rendelet szárított zöldségre maximálisan $4 \mathrm{mg} / \mathrm{kg}$ As-, $2 \mathrm{mg} / \mathrm{kg} \mathrm{Pb}-, 0,3 \mathrm{mg} / \mathrm{kg}$ Cd- és $0,05 \mathrm{mg} / \mathrm{kg} \mathrm{Hg}$-koncentrációt engedélyez. Egyéb elemekre nem ad meg határértékeket. Takarmánykeverékek a következő mennyiségeket tartalmazhatnak: As

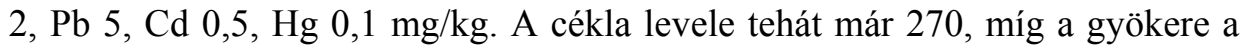
$810 \mathrm{~kg} / \mathrm{ha}$ terhelésnél eredményezhet állati vagy emberi fogyasztásra alkalmatlan terméket ezen a talajon.

A Ba-koncentráció is mérsékelten növekedett, mindössze megduplázódott a maximális Ba-terhelés nyomán. A Cd-dúsulás aggodalomra adhat okot, hiszen két nagyságrendet elérve a növényi részekben erősen szennyezett termést adott. A gyökér sem védett a káros hatás ellen. Egy nagyságrenddel dúsult a króm és már a szennyezetlen talajon 1-4 mg/kg közötti értéket mutatott. A Cu-tartalom átlagosan mindössze megkétszereződött a növényi részekben, a termés még nem tekinthető szennyezettnek. Ezzel szemben már a $90 \mathrm{~kg} / \mathrm{ha}$ Hg-terhelésnél a növényi minőség kifogásolható, ill. a határérték felett szennyezetté válik (6. táblázat).

A molibdén extrém mértékben halmozódik, az akkumuláció három nagyságrendbeli. Ismeretes, hogy a molibdén - a transzspirációs árammal bejutva - föként a föld feletti hajtásban, ill. levelekben dúsulhat. Ez a jelenség nem jár együtt terméscsökkenéssel, az extrém Mo-túlsúly nem okoz fitotoxicitást. A növényevő ember vagy állat számára az ilyen összetételü termék azonban már elfogadhatatlan. Az 5 mg/kg feletti Mo-koncentrációt károsnak minősítjük, mert 
6. táblázat

Kezelések hatása a légszáraz cékla elemtartalmára 1995-ben (Karbonátos csernozjom talaj, Nagyhörcsök)

\begin{tabular}{|c|c|c|c|c|c|c|}
\hline \multirow{2}{*}{$\begin{array}{c}\text { (1) } \\
\text { Növényi } \\
\text { rész }\end{array}$} & \multicolumn{4}{|c|}{$\begin{array}{c}\text { (2) } \\
\text { Terhelés } 1991 \text { tavaszán, kg/ha }\end{array}$} & \multirow{2}{*}{$\begin{array}{c}(3) \\
\mathbf{S z D}_{\mathbf{5} \%}\end{array}$} & \multirow[t]{2}{*}{ Átlag } \\
\hline & $\mathbf{0}$ & 90 & 270 & 810 & & \\
\hline \multicolumn{7}{|c|}{ A. As-terhelés hatására, mg As/kg } \\
\hline a) levél ${ }^{1}$ & 0,0 & 0,0 & 2,0 & 13,4 & 1,0 & 3,8 \\
\hline b) levél ${ }^{2}$ & 0,0 & 0,0 & 5,6 & 12,2 & 1,5 & 4,4 \\
\hline c) gyökér ${ }^{2}$ & 0,0 & 0,0 & 0,0 & 9,2 & 1,2 & 2,3 \\
\hline \multicolumn{7}{|c|}{ B. Ba-terhelés hatására, $\mathrm{mg} \mathrm{Ba} / \mathrm{kg}$} \\
\hline a) levél ${ }^{1}$ & 62 & 79 & 109 & 144 & 18 & 99 \\
\hline b) levél ${ }^{2}$ & 75 & 88 & 112 & 118 & 24 & 98 \\
\hline c) gyökér ${ }^{2}$ & 23 & 33 & 38 & 43 & 7 & 34 \\
\hline \multicolumn{7}{|c|}{ C. Cd-terhelés hatására, $m g \mathrm{Cd} / \mathrm{kg}$} \\
\hline a) levél ${ }^{1}$ & 0,4 & 31 & 56 & 68 & 3 & 39 \\
\hline b) levél ${ }^{2}$ & 0,4 & 27 & 47 & 80 & 9 & 38 \\
\hline c) gyökér ${ }^{2}$ & 0,4 & 18 & 47 & 55 & 10 & 30 \\
\hline \multicolumn{7}{|c|}{ D. Cr-terhelés hatására, $m g \mathrm{Cr} / \mathrm{kg}$} \\
\hline a) levél ${ }^{1}$ & 1,5 & 5 & 15 & 18 & 2 & 10 \\
\hline b) levél ${ }^{2}$ & 4,1 & 10 & 29 & 38 & 3 & 20 \\
\hline c) gyökér ${ }^{2}$ & 1,0 & 4 & 8 & 13 & 2 & 6 \\
\hline \multicolumn{7}{|c|}{ E. Cu-terhelés hatására, mg Cu/kg } \\
\hline a) levél ${ }^{1}$ & 10 & 11 & 14 & 18 & 3 & 13 \\
\hline b) levél ${ }^{2}$ & 8 & 13 & 17 & 22 & 3 & 15 \\
\hline c) gyökér ${ }^{2}$ & 9 & 11 & 12 & 15 & 2 & 12 \\
\hline \multicolumn{7}{|c|}{ F. Hg-terhelés hatására, $\mathrm{mg} \mathrm{Hg} / \mathrm{kg}$} \\
\hline a) levél ${ }^{1}$ & 0,0 & 0,6 & 5,1 & 8,9 & 1,3 & 3,8 \\
\hline b) levél ${ }^{2}$ & 0,0 & 1,6 & 4,6 & 14,2 & 2,8 & 5,1 \\
\hline c) gyökér ${ }^{2}$ & 0,0 & 0,5 & 1,2 & 6,8 & 1,6 & 2,1 \\
\hline \multicolumn{7}{|c|}{ G. Mo-terhelés hatására, mg Mo/kg } \\
\hline a) levél ${ }^{1}$ & 0,1 & 243 & 459 & 916 & 35 & 405 \\
\hline b) levél ${ }^{2}$ & 0,0 & 182 & 451 & 852 & 15 & 371 \\
\hline c) gyökér ${ }^{2}$ & 0,0 & 37 & 70 & 114 & 8 & 55 \\
\hline \multicolumn{7}{|c|}{ H. Ni-terhelés hatására, $m g \mathrm{Ni} / \mathrm{kg}$} \\
\hline a) levél ${ }^{1}$ & 0,9 & 2,1 & 3,5 & 14,0 & 1,0 & 5,1 \\
\hline b) levél ${ }^{2}$ & 3,0 & 5,0 & 8,9 & 27,2 & 1,9 & 11,0 \\
\hline c) gyökér ${ }^{2}$ & 1,5 & 3,3 & 5,1 & 8,4 & 0,6 & 4,6 \\
\hline
\end{tabular}


6. táblázat folytatása

\begin{tabular}{|c|c|c|c|c|c|c|}
\hline \multirow{2}{*}{$\begin{array}{l}\text { (1) } \\
\text { Növényi } \\
\text { rész }\end{array}$} & \multicolumn{4}{|c|}{$\begin{array}{c}(2) \\
\text { Terhelés } 1991 \text { tavaszán, kg/ha }\end{array}$} & \multirow{2}{*}{$\begin{array}{c}(3) \\
\mathbf{S z D}_{\mathbf{5}}\end{array}$} & \multirow{2}{*}{ Átlag } \\
\hline & $\mathbf{0}$ & 90 & 270 & 810 & & \\
\hline \multicolumn{7}{|c|}{ I. Pb-terhelés hatására, $\mathrm{mg} \mathrm{Pb/kg}$} \\
\hline a) levél ${ }^{1}$ & 0,5 & 1,8 & 2,6 & 6,9 & 1,5 & 2,9 \\
\hline b) levél ${ }^{2}$ & 1,0 & 3,6 & 8,1 & 14,6 & 1,9 & 6,8 \\
\hline c) gyökér ${ }^{2}$ & 0,0 & 0,2 & 1,6 & 3,0 & 0,8 & 1,2 \\
\hline \multicolumn{7}{|c|}{ J. Se-terhelés hatására, mg Se/kg } \\
\hline a) levél ${ }^{1}$ & 1 & 434 & $(-)$ & $(-)$ & 23 & 218 \\
\hline b) levél ${ }^{2}$ & 1 & 608 & $(-)$ & $(-)$ & 39 & 305 \\
\hline c) gyökér ${ }^{2}$ & 1 & 143 & $(-)$ & $(-)$ & 10 & 72 \\
\hline \multicolumn{7}{|c|}{ K. Sr-terhelés hatására, $\mathrm{mg} \mathrm{Sr/kg}$} \\
\hline a) levél ${ }^{1}$ & 98 & 149 & 223 & 552 & 42 & 256 \\
\hline b) levél ${ }^{2}$ & 140 & 270 & 298 & 778 & 47 & 372 \\
\hline c) gyökér ${ }^{2}$ & 45 & 63 & 67 & 161 & 18 & 84 \\
\hline \multicolumn{7}{|c|}{ L. Zn-terhelés hatására, $m g \mathrm{Zn} / \mathrm{kg}$} \\
\hline a) levél ${ }^{1}$ & 20 & 42 & 51 & 83 & 15 & 49 \\
\hline b) levél ${ }^{2}$ & 12 & 24 & 42 & 72 & 7 & 38 \\
\hline c) gyökér ${ }^{2}$ & 18 & 46 & 70 & 96 & 8 & 58 \\
\hline
\end{tabular}

${ }^{1}$ - tenyészidő közepén 1995. jún. 21-én, ${ }^{2}$ - betakarításkor 1995. szept. 7-én; (-): növényzet kipusztult. As- és Hg-tartalom $0,1 \mathrm{mg} / \mathrm{kg}$ alatt szennyezetlen talajon

Cu-hiányt indukálhat, míg az extrém Mo-túlsúly toxikózist okozhat. A Ni-felvétel egy nagyságrendbeli dúsulással járt a levélben, némileg mérsékeltebb volt a gyökérben.

A Pb-koncentráció a gyökér esetében és a fiatal levélben csak a maximális $810 \mathrm{~kg} / \mathrm{ha}$ terhelésnél haladta meg a határértéket. A Se-tartalom föként az elöregedő levélben már a $90 \mathrm{~kg} / \mathrm{ha}$ adagnál több százszorosára nőtt. Az e feletti terhelésnél a cékla kipusztult. Tehát a molibdenát és szelenát anion-formák fél évtized után is mobilisak maradhatnak ebben a meszes, jól szellőzött talajban. A molibdéntől eltérően azonban a szelén fitotoxicitása kifejezett. A stroncium átlagosan 4-5-szörös maximális felhalmozást jelez a növényi részekben. A kevésbé veszélyes jelleg miatt a szabványok nem közölnek határértékeket a Sr elemre. Az extrém Se-túlsúly természetesen toxikózishoz vezethet állatban és emberben. A Zn-koncentráció a Sr-hoz hasonlóan 4-5-szörös dúsulást mutatott (6. táblázat).

Megemlítjük, hogy a szárazság miatt a cékla fiatal lombja, ill. a betakarításkori gyökere egyaránt nagy $\mathrm{NO}_{3}-\mathrm{N}-$ koncentrációkat tükrözött. Amint a 7. táblázat adatai mutatják, az As-terheléssel igazolhatóan emelkedett a $\mathrm{NO}_{3}$-N-tartalom mind a levélben, mind a gyökérben, elérve a 3400-4000 mg/kg értékeket. 
Szignifikánsan nőtt a szelénnel szennyezett gyökér $\mathrm{NO}_{3}$-N-készlete is. A nitrát közismerten tartaléktápanyag, melyet a növény aminosavakba és fehérjékbe épít be. Úgy tünik, hogy a $\mathrm{NO}_{3}$-redukciót mind az As-, mind a Se-túlsúlya gátolhatja, anyagcserezavarokat okozva.

7. táblázat

Kezelések hatása a légszáraz cékla NO$_{3}$-N-tartalmára, 1995

(Karbonátos csernozjom talaj, Nagyhörcsök)

\begin{tabular}{|c|c|c|c|c|c|c|}
\hline \multirow{2}{*}{$\begin{array}{c}(1) \\
\text { Elem }\end{array}$} & \multicolumn{4}{|c|}{ (2) Terhelés 1991 tavaszán, kg/ha } & \multirow{2}{*}{$\begin{array}{c}(3) \\
\text { SzD }_{\mathbf{5} \%}\end{array}$} & \multirow{2}{*}{ Átlag } \\
\hline & $\mathbf{0}$ & 90 & 270 & 810 & & \\
\hline \multicolumn{7}{|c|}{ A. Levélben jún. 21-én, $m g / g$} \\
\hline As & 1,41 & 1,38 & 2,17 & 3,42 & & 2,09 \\
\hline $\mathrm{Cd}$ & 1,74 & 2,69 & 2,59 & 2,61 & 1,09 & 2,41 \\
\hline $\mathrm{Cr}$ & 1,88 & 1,31 & 1,36 & 2,91 & & 1,86 \\
\hline $\mathrm{Se}$ & 1,81 & 1,66 & $(-)$ & $(-)$ & & 1,44 \\
\hline \multicolumn{7}{|c|}{ B. Gyökérben szept. 7-én, $\mathrm{mg} / \mathrm{g}$} \\
\hline As & 1,73 & 2,34 & 2,50 & 3,99 & & 2,98 \\
\hline $\mathrm{Cd}$ & 1,72 & 2,22 & 1,95 & 2,50 & 0,99 & 2,10 \\
\hline $\mathrm{Cr}$ & 1,78 & 2,53 & 1,43 & 2,14 & & 1,97 \\
\hline $\mathrm{Se}$ & 1,95 & 3,42 & $(-)$ & $(-)$ & & 2,68 \\
\hline
\end{tabular}

(-): növényzet kipusztult

A cékla átlagos összetételét szennyezetlen talajon a 8. táblázatban vizsgálhatjuk. Megállapítható, hogy a répafélékre jellemzően a lombban kiugróan nagy lehet a $\mathrm{K}, \mathrm{Ca}, \mathrm{Na}, \mathrm{Mg}$ elemekben való dúsulás. Más kultúrákhoz (kalászosok, kukorica) viszonyítva emelkedett koncentrációt mutat a levélben a $\mathrm{S}$ és $\mathrm{P}$ is, valamint egy nagyságrenddel gazdagabb $\mathrm{Cr}, \mathrm{Co}, \mathrm{Ni}, \mathrm{Cd}, \mathrm{Se}, \mathrm{Pb}$, Mo nyomelemekben. A gyökér ásványi elemekben szegényebb, mint a lomb. Ez alól kivételt a $\mathrm{K}, \mathrm{N}, \mathrm{NO}_{3}-\mathrm{N}, \mathrm{Zn}, \mathrm{Cu}$ jelentett. A 25 vizsgált elemböl méréshatár, ill. 0,1 $\mathrm{mg} / \mathrm{kg}$ koncentráció alatt maradt az As, $\mathrm{Hg}$, Mo.

$\mathrm{Az}$ összes felvett $\mathrm{K}, \mathrm{N}, \mathrm{NO}_{3}-\mathrm{N}, \mathrm{P}, \mathrm{B}, \mathrm{Zn}, \mathrm{Cu}, \mathrm{Ni}, \mathrm{Cd}$, Se elemek nagyobb része a gyökérben, míg a $\mathrm{Ca}, \mathrm{Mg}, \mathrm{Na}, \mathrm{S}, \mathrm{Al}, \mathrm{Fe}$ nagyobb tömege a föld feletti levélben akkumulálódott. A mérsékelt 15-20 t/ha friss, ill. 2,5-3,0 t/ha légszáraz gyökértömeg a hozzá tartozó lombbal együtt $112 \mathrm{~kg} \mathrm{~K}-(134 \mathrm{~kg} \mathrm{~K} \mathrm{O}), 89 \mathrm{~kg}$ $\mathrm{N}-, 12 \mathrm{~kg} \mathrm{P}-\left(28 \mathrm{~kg} \mathrm{P} \mathrm{O}_{5}\right), 50 \mathrm{~kg} \mathrm{Ca}-, 35 \mathrm{~kg} \mathrm{Mg}-, 28 \mathrm{~kg} \mathrm{Na}-, 13 \mathrm{~kg} \mathrm{~S}-$, ill. 3-3 kg Al- és Fe-készlettel rendelkezett betakarításkor. A szaktanácsadásban használatos fajlagos, azaz $10 \mathrm{t}$ tervezett fötermés elemigénye lombbal együtt az alábbiaknak adódott: $44 \mathrm{~kg} \mathrm{~N}, 6 \mathrm{~kg} \mathrm{P}\left(14 \mathrm{~kg} \mathrm{P}_{2} \mathrm{O}_{5}\right), 56 \mathrm{~kg} \mathrm{~K}\left(67 \mathrm{~kg} \mathrm{~K} \mathrm{O}_{2} \mathrm{O}\right), 25 \mathrm{~kg}$ $\mathrm{Ca}, 18 \mathrm{~kg} \mathrm{Mg}$. A kiugróan nagy fajlagos N-tartalom az aszályos évnek tulajdonítható. 
A kísérletünkben talált fajlagos mutatók közül a nitrogén $25 \%$-kal nagyobb, míg a foszfor $34 \%$-kal, a kálium $25 \%$-kal kisebb értéket mutatott, mint a SzABÓ (1994) által megadott. Száraz évben a növények közismerten több nitrogént tartalmaznak és a tápoldat is betöményedik, nincs kilúgozás, ill. a növényben hígulás sem lép fel. A szaktanácsadás számára a $25 \mathrm{~kg} \mathrm{~N}, 10 \mathrm{~kg} \mathrm{P}_{2} \mathrm{O}_{5}$, $45 \mathrm{~kg} \mathrm{~K} \mathrm{~K}_{2} \mathrm{O}$ fajlagos értékekkel számolhatunk hasonló körülmények között, ill. hasonló talajon (9. táblázat).

Szennyezett talajon a maximális mikroelem-felvétel (gyökér+lomb betakarításkor) $1600 \mathrm{~g} \mathrm{Sr}, 1200 \mathrm{~g} \mathrm{Mo,} 800 \mathrm{~g} \mathrm{Se}, 360 \mathrm{~g} \mathrm{Zn}, 240 \mathrm{~g} \mathrm{Ba}, 80 \mathrm{~g} \mathrm{Cd}, 70 \mathrm{~g} \mathrm{Cu}$,

8. táblázat

A légszáraz cékla átlagos elemtartalma szennyezetlen talajon, 1995 (Karbonátos csernozjom talaj, Nagyhörcsök)

\begin{tabular}{|l|c|c|c|c|}
\hline \multirow{2}{*}{$\begin{array}{c}\text { Elem } \\
\text { jele }\end{array}$} & \multirow{2}{*}{$\begin{array}{c}\text { Mérték- } \\
\text { egység }\end{array}$} & \multicolumn{2}{|c|}{$\begin{array}{c}\text { (3) } \\
\text { Levél }\end{array}$} & $\begin{array}{c}(4) \\
\text { Gyökér } \\
\text { szept. 11-én }\end{array}$ \\
\cline { 3 - 4 } $\mathrm{K}$ & $\%$ & 7,99 & 2,74 & 2,83 \\
$\mathrm{~N}$ & $\%$ & 3,46 & 2,40 & 2,17 \\
$\mathrm{Ca}$ & $\%$ & 2,10 & 3,42 & 0,52 \\
$\mathrm{Na}$ & $\%$ & 1,37 & 1,80 & 0,35 \\
$\mathrm{Mg}$ & $\%$ & 1,02 & 2,20 & 0,50 \\
$\mathrm{~S}$ & $\%$ & 0,62 & 0,71 & 0,19 \\
$\mathrm{P}$ & $\%$ & 0,51 & 0,42 & 0,27 \\
$\mathrm{Al}$ & $\%$ & 0,11 & 0,24 & 0,05 \\
$\mathrm{NO} O_{3}-\mathrm{N}$ & $\%$ & 0,17 & 0,24 & 0,23 \\
$\mathrm{Fe}$ & $\%$ & 0,08 & 0,24 & 0,05 \\
$\mathrm{Mn}$ & $\mathrm{mg} / \mathrm{kg}$ & 205 & 342 & 102 \\
$\mathrm{Sr}$ & $\mathrm{mg} / \mathrm{kg}$ & 93 & 140 & 45 \\
$\mathrm{Ba}$ & $\mathrm{mg} / \mathrm{kg}$ & 62 & 75 & 22 \\
$\mathrm{~B}$ & $\mathrm{mg} / \mathrm{kg}$ & 49 & 30 & 25 \\
$\mathrm{Zn}$ & $\mathrm{mg} / \mathrm{kg}$ & 24 & 11 & 18 \\
$\mathrm{Cu}$ & $\mathrm{mg} / \mathrm{kg}$ & 10 & 8 & 8 \\
$\mathrm{Cr}$ & $\mathrm{mg} / \mathrm{kg}$ & 1,40 & 3,40 & 1,15 \\
$\mathrm{Co}$ & $\mathrm{mg} / \mathrm{kg}$ & 0,54 & 1,12 & 0,28 \\
$\mathrm{Ni}$ & $\mathrm{mg} / \mathrm{kg}$ & 0,50 & 3,02 & 1,80 \\
$\mathrm{Cd}$ & $\mathrm{mg} / \mathrm{kg}$ & 0,33 & 0,35 & 0,20 \\
$\mathrm{Se}$ & $\mathrm{mg} / \mathrm{kg}$ & 0,33 & 0,23 & 0,20 \\
$\mathrm{~Pb}$ & $\mathrm{mg} / \mathrm{kg}$ & 0,28 & 0,99 & 0,30 \\
\hline
\end{tabular}

Megjegyzés: As, $\mathrm{Hg}$ és Mo 0,1 mg/kg alatt. A levél jún. 21-én átlagosan $9 \%$, szept. 7én $18 \%$, a gyökér szept. 11-én $14 \%$ légszáraz anyagot tartalmazott 
9. táblázat

A cékla átlagos és fajlagos (10 t betakarításkori friss gyökér + a hozzá tartozó lomb) elemfelvétele szennyezetlen talajon, 1995

(Karbonátos csernozjom talaj, Nagyhörcsök)

\begin{tabular}{|c|c|c|c|c|c|}
\hline \multirow{2}{*}{$\begin{array}{c}(1) \\
\text { Elem } \\
\text { jele } \\
\end{array}$} & \multirow{2}{*}{$\begin{array}{c}\text { (2) } \\
\text { Mérték- } \\
\text { egység }\end{array}$} & \multicolumn{3}{|c|}{ (3) Felvett elemek betakarításkor } & \multirow{2}{*}{$\begin{array}{c}(7) \\
\text { Fajlagos } \\
\text { kg/10 t }\end{array}$} \\
\hline & & $\begin{array}{c}\text { (4) } \\
\text { Lomb }\end{array}$ & $\begin{array}{c}\text { (5) } \\
\text { Gyökér }\end{array}$ & $\begin{array}{c}\text { (6) } \\
\text { Összesen }\end{array}$ & \\
\hline K & $\mathrm{kg} / \mathrm{ha}$ & 27 & 85 & 112 & 56 \\
\hline $\mathrm{N}$ & $\mathrm{kg} / \mathrm{ha}$ & 24 & 65 & 89 & 44 \\
\hline $\mathrm{Ca}$ & $\mathrm{kg} / \mathrm{ha}$ & 34 & 16 & 50 & 25 \\
\hline $\mathrm{Mg}$ & $\mathrm{kg} / \mathrm{ha}$ & 22 & 15 & 37 & 18 \\
\hline $\mathrm{Na}$ & $\mathrm{kg} / \mathrm{ha}$ & 18 & 10 & 28 & 14 \\
\hline $\mathrm{S}$ & $\mathrm{kg} / \mathrm{ha}$ & 7.1 & 5.7 & 13 & 6 \\
\hline $\mathrm{P}$ & $\mathrm{kg} / \mathrm{ha}$ & 4.2 & 8.1 & 12 & 6 \\
\hline $\mathrm{NO}_{3}-\mathrm{N}$ & $\mathrm{kg} / \mathrm{ha}$ & 2.4 & 6.9 & 9 & 4 \\
\hline $\mathrm{Al}$ & $\mathrm{kg} / \mathrm{ha}$ & 2.4 & 0.2 & 3 & 1 \\
\hline $\mathrm{Fe}$ & $\mathrm{kg} / \mathrm{ha}$ & 2.4 & 0.2 & 3 & 1 \\
\hline $\mathrm{Mn}$ & $\mathrm{g} / \mathrm{ha}$ & 342 & 306 & 648 & 324 \\
\hline $\mathrm{Sr}$ & $\mathrm{g} / \mathrm{ha}$ & 140 & 135 & 275 & 137 \\
\hline $\mathrm{Ba}$ & $\mathrm{g} / \mathrm{ha}$ & 76 & 66 & 142 & 70 \\
\hline B & $\mathrm{g} / \mathrm{ha}$ & 30 & 75 & 105 & 52 \\
\hline $\mathrm{Zn}$ & $\mathrm{g} / \mathrm{ha}$ & 11 & 54 & 65 & 32 \\
\hline $\mathrm{Cu}$ & $\mathrm{g} / \mathrm{ha}$ & 8 & 24 & 32 & 16 \\
\hline $\mathrm{Cr}$ & $\mathrm{g} / \mathrm{ha}$ & 3.4 & 3.4 & 6.8 & 3 \\
\hline $\mathrm{Ni}$ & $\mathrm{g} / \mathrm{ha}$ & 3.0 & 5.4 & 8.4 & 4 \\
\hline Co & $\mathrm{g} / \mathrm{ha}$ & 1.1 & 0.8 & 1.9 & 1 \\
\hline $\mathrm{Pb}$ & $\mathrm{g} / \mathrm{ha}$ & 1.0 & 0.9 & 1.9 & 1 \\
\hline $\mathrm{Cd}$ & $\mathrm{g} / \mathrm{ha}$ & 0.4 & 0.6 & 1.0 & 0.5 \\
\hline $\mathrm{Se}$ & $\mathrm{g} / \mathrm{ha}$ & 0.2 & 0.6 & 0.8 & 0.4 \\
\hline
\end{tabular}

Megjegyzés: As, Hg, Mo felvétele méréshatár alatt maradt. Maximális felvétel szenynyezett talajon: Sr 1600, Mo 1200, Se 800, Zn 360, Ba 240, Cd 80, Cu 70, Cr és Ni 50, As és $\mathrm{Hg} 40, \mathrm{~Pb} 24 \mathrm{~g} / \mathrm{ha}$

50 g Cr és Ni, 40 g As és $\mathrm{Hg}$, valamint 24 g Pb mennyiséget tett ki hektáronként. Az erősen szennyezett talajok tisztítása tehát fitoremediációval nem jelenthet perspektívát. Ha feltesszük, hogy a termés tömegét öntözéssel, jobb agrotechnikával, új fajtával megtízszerezhetjük a jövőben, a $910 \mathrm{~kg} / \mathrm{ha}$ Cd-terhelés eltüntetéséhez (az évenkénti $800 \mathrm{~g} /$ ha kivonással számolva) pl. egy évezredre lenne szükség. 


\section{Összefoglalás}

Löszön képződött vályog mechanikai összetételü karbonátos csernozjom talajon, az MTA Talajtani és Agrokémiai Kutatóintézet Nagyhörcsöki Kísérleti Telepén szabadföldi kisparcellás mikroelem-terhelési kísérletet állítottunk be 1991 tavaszán. A termőhely talajának szántott rétege mintegy $5 \% \mathrm{CaCO}_{3}$-ot és $3 \%$ humuszt tartalmazott, felvehető tápelemekkel való ellátottsága: $\mathrm{Ca}, \mathrm{Mg}$, $\mathrm{Mn}, \mathrm{Cu}$ kielégítő, $\mathrm{N}$ és $\mathrm{K}$ közepes, $\mathrm{P}$ és $\mathrm{Zn}$ gyenge volt. A talajvíz $15 \mathrm{~m}$ mélyen helyezkedik el, a terület vízmérlege negatív, aszályra hajló. A 13 vizsgált mikroelem sóit 4-4 szinten alkalmaztuk 1991 tavaszán, a kukorica vetése elött. A 13 x $4=52$ kezelést 2 ismétlésben állítottuk be, összesen 104 parcellán, splitplot elrendezésben. A terhelési szintek $0,90,270,810 \mathrm{~kg} / \mathrm{ha}$ mennyiséget jelentettek elemenként $\mathrm{AlCl}_{3}, \mathrm{NaAsO}_{2}, \mathrm{BaCl}_{2}, \mathrm{CdSO}_{4}, \mathrm{~K}_{2} \mathrm{CrO}_{4}, \mathrm{CuSO}_{4}, \mathrm{HgCl}_{2}$, $\left(\mathrm{NH}_{4}\right)_{6} \mathrm{Mo}_{7} \mathrm{O}_{24}, \mathrm{NiSO}_{4}, \mathrm{~Pb}\left(\mathrm{NO}_{3}\right)_{2}, \mathrm{Na}_{2} \mathrm{SeO}_{3}, \mathrm{SrSO}_{4}, \mathrm{ZnSO}_{4}$ formájában. A 100 $100-100 \mathrm{~kg} / \mathrm{ha} \mathrm{N}-\mathrm{P}_{2} \mathrm{O}_{5}-\mathrm{K}_{2} \mathrm{O}$ alaptrágyázás egységesen történt az egész kísérletben ammonnitrát-, szuperfoszfát- és kálisómütrágyákkal. A növényi sorrend kukorica, sárgarépa, burgonya és borsó volt. Az 5. évben végzett cékla kísérletünk eredményeit az alábbiakban foglaljuk össze:

1. Talajvizsgálatokkal a terhelés csak részben és elemenként eltérő módon je-lezhető utólag. A cc. $\mathrm{HNO}_{3}+$ cc. $\mathrm{H}_{2} \mathrm{O}_{2}$ feltárásból az alábbi visszamérhetőség adódott: 90 \% felett kimutatható volt az $\mathrm{Pb}, \mathrm{Sr}, \mathrm{Ba}, \mathrm{Ni}, \mathrm{Zn} ; 60-90$ \% között a $\mathrm{Cu}, \mathrm{Se}, \mathrm{As}, \mathrm{Hg} ; 30-60 \%$ között a $\mathrm{Cr}, \mathrm{Cd}, \mathrm{Mo} . \mathrm{Az} \mathrm{NH}$-acetát + EDTA-oldható frakcióból 90 \% felett az Pb; 60-90 \% között a Sr; 30-60 \% között a Cu, Zn Cd, $\mathrm{Ni}, \mathrm{Se} ; 10-30$ \% között az As, Ba, Mo, $\mathrm{Hg} ; 10 \%$ alatt a Cr volt detektálható öt év után a szántott rétegben. Az Al-dúsulás egyik módszerrel sem volt igazolható. Külön vizsgálatot igényel majd a veszteségforrások feltárása (megkötődés, kilúgozás, elillanás, felvétel).

2. A 13 vizsgált elemből az $\mathrm{As}, \mathrm{Cd}, \mathrm{Cr}$, Se bizonyult toxikusnak a céklára. A száraz évben szennyezetlen talajon 15-20 t/ha gyökér termett, mely a maximális Cd-terheléssel 1,5 t/ha, a maximális Cr-terheléssel 3,5 t/ha mennyiségre csökkent. Az 5 évvel ezelött adott 270, ill. $810 \mathrm{~kg} / \mathrm{ha}$ Se-terhelés a cékla és a gyomok teljes pusztulását eredményezte. Az As-terhelés negatív hatása a betakarításkori gyökértermésben már nem jelentkezett.

3. Maximális elemdúsulásokat általában a betakarításkori levél mutatott, de a gyökérben is közelálló tartalmak alakultak ki. A kontrollhoz képest 2-3 nagyságrendbeli dúsulást jeleztek a növényi szervek az As, $\mathrm{Cd}, \mathrm{Hg}$, Mo és Se esetén. Mérsékelt, néhányszoros koncentrációnövekedés fordult elő a $\mathrm{Ba}, \mathrm{Cu}, \mathrm{Sr}$ és $\mathrm{Zn}$ elemekben. Átlagosan egy nagyságrenddel nőtt viszont a Cr-, Ni- és Pb-tartalom az erősen szennyezett talajon. 
4. A 10 t gyökér + a hozzá tartozó lombtermés fajlagos elemigénye kg-ban az alábbinak adódott: $44 \mathrm{~kg} \mathrm{~N}, 6 \mathrm{~kg} \mathrm{P}\left(14 \mathrm{~kg} \mathrm{P}_{2} \mathrm{O}_{5}\right), 56 \mathrm{~kg} \mathrm{~K}\left(67 \mathrm{~kg} \mathrm{~K} \mathrm{~K}_{2} \mathrm{O}\right), 25 \mathrm{~kg}$ $\mathrm{Ca}, 18 \mathrm{~kg} \mathrm{Mg}$. A kiugróan nagy fajlagos $\mathrm{N}$-tartalom az aszályos évnek tulajdonítható. Adataink iránymutatóul szolgálhatnak a szaktanácsadás számára.

5. Szennyezett talajon a maximális elemfelvétel (gyökér + lomb betakarításkor) $1600 \mathrm{~g} \mathrm{Sr}, 1200 \mathrm{~g} \mathrm{Mo}, 800 \mathrm{~g} \mathrm{Se}, 360 \mathrm{~g} \mathrm{Zn}, 240 \mathrm{~g} \mathrm{Ba}, 80 \mathrm{~g} \mathrm{Cd}, 70 \mathrm{~g} \mathrm{Cu}$, $50 \mathrm{~g} \mathrm{Cr}$ és Ni, $40 \mathrm{~g}$ As és $\mathrm{Hg}$, valamint $24 \mathrm{~g} \mathrm{~Pb}$ mennyiséget tett ki hektáronként. Erösen szennyezett talajokon a fitoremediáció nem lehet igazi perspektíva. Ha pl. az intenzív elemakkumulációra képes cékla termését egy nagyságrenddel növelhetnénk a jövőben (évenként $800 \mathrm{~g} / \mathrm{ha}$ Cd-felvételt elérve), egy évezredre volna szükség a talaj remediációjára.

\section{Irodalom}

BERGMANN, W., 1988. Ernährungsstörungen bei Kulturpflanzen. VEB Gustav Fischer Verlag. Jena.

CsATHÓ P., 1994. A környezet nehézfém-szennyezettsége és az agrártermelés. Tematikus szakirodalmi szemle. MTA TAKI. Budapest.

FiLEP Gy., 1988. Talajkémia. Akadémiai Kiadó. Budapest.

FiLIUS I.. 1994. A zöldségnövények tápanyagai. In: Zöldségtermesztők kézikönyve. 2. jav. kiadás. (Szerk.: BALÁzs S.) 73-91. Mezőgazda Kiadó. Budapest.

EüM 1985. Az egészségügyi miniszter 8/1985. (X.21.) EüM sz. rendelete az élelmiszerek vegyi szennyeződésének elhárításáról. Egészségügyi Közlöny. 20. 642644.

KÁDÁR I., 2001. Mikroelem-terhelés hatása a borsóra karbonátos csernozjom talajon. I. Termés és ásványi összetétel. Agrokémia és Talajtan. 50. 62-82.

KÁDÁR I. \& PROKISCH J., 2000. Mikroelem-terhelés hatása a burgonya termésére és elemtartalmára karbonátos csernozjom talajon. Agrokémia és Talajtan. 49. 447464.

KÁDÁR I., RADICS L. \& BANA K-NÉ, 2000. Mikroelem-terhelés hatása a kukoricára karbonátos csernozjom talajon. Agrokémia és Talajtan. 49. 181-204.

KÁDÁR I., RADICS L. \& DAOOD, H., 2000a. Mikroelem-terhelés hatása a sárgarépa termésére karbonátos csernozjom talajon. Agrokémia és Talajtan. 49. 427-446.

LAKANEN, E. \& ERVIÖ, R., 1971. A comparison of eight extractants for the determination of plant available micronutrients in soils. Acta Agr. Fenn. 123. 223-232.

LEHOCZKY É., 1994. A gyomnövények és a kultúrnövények versengése a tápanyagokért. In: Trágyázási kutatások. (Szerk:: DEBRECZENI B. \& DeBRECZENI B-NÉ) 355-360. Akadémiai Kiadó. Budapest.

LEHOCZKY É., DEBRECZENI B-NÉ \& KARAMÁN J., 1988. Az öszi búza és néhány gyomnövény tápanyagtartalmának és felvételének vizsgálata üzemi táblákon. Növénytermelés. 37. 115-123. 
LehoczKy, É., SzABAdos, I. \& MARTH, P., 1996. Cadmium content of plants as affected by soil cadmium concentration. In: Soil and Plant Analysis in Sustainable Agriculture and Environment. (Ed.: Hood, T. M. \& JONES, J. B.). 827-839. Marcel Dekker, Inc. New York.

LEHOCZKY, É. et al., 1998. Cadmium uptake by lettuce in different soils. Commun. Soil Sci. Plant Anal. 29. 1903-1912.

LEHOCZKY, É. et al., 1998a. Effect of liming on the heavy metal uptake of lettuce. Agrokémia és Talajtan. 47. 229-234.

LOCH, J., 1992. Ermittlung optimaler Düngergaben und Nährstoffverhältnisse als Voraussetzung für eine umweltschonende Düngung. 104. VDLUFA Kongressband. 195-198. Göttingen.

MÉM NAK: 1979. Műtrágyázási irányelvek és üzemi számítási módszer. MÉM Növényvédelmi és Agrokémiai Központ. Budapest.

NÉMETH, T. et al., 1993. Mobility of some heavy metals in soil-plant system studied on soil monoliths. Water Sci. Tech. 28. 389-398.

SIMON L., 1998. Talajszennyeződés, talajtisztítás. GATE Mezőgazdasági Főiskolai Kara. Nyíregyháza.

SzABÓ L., 1994. Cékla. In.: Zöldségtermesztők kézikönyve. 2. jav. kiadás. (Szerk.: BALÁZS S.) 578-284. Mezőgazda Kiadó. Budapest.

VERMES L., 1994. A talajszennyezés néhány kérdése. Talajvédelem. 2. 86-93.

Érkezett: 2001. április 17. 


\title{
Effect of Microelement Loads on Beetroot Grown on Calcareous Chernozem Soil
}

\author{
${ }^{1}$ I. KÁDÁR, ${ }^{1}$ J. KONCZ and ${ }^{2}$ L. RADICS
}

${ }^{1}$ Research Institute for Soil Science and Agricultural Chemistry of the Hungarian Academy of Sciences, Budapest and ${ }^{2}$ Faculty of Horticultural Science, Szent István University, Budapest

\begin{abstract}
Summary
A small-plot field experiment was set up in spring 1991 at the Nagyhörcsök Experimental Station of the Research Institute for Soil Science and Agricultural Chemistry of the Hungarian Academy of Sciences on a calcareous chernozem soil with loam texture, formed on loess, in order to study the effect of microelement contamination. The ploughed layer of the experimental site contained around $5 \% \mathrm{CaCO}_{3}$ and $3 \%$ humus, and was well-supplied with $\mathrm{Ca}, \mathrm{Mg}, \mathrm{Mn}$ and $\mathrm{Cu}$, moderately with $\mathrm{N}$ and $\mathrm{K}$, and poorly supplied with $\mathrm{P}$ and $\mathrm{Zn}$. The groundwater was at a depth of $15 \mathrm{~m}$, and the area had a negative water balance, being prone to drought. The salts of the 13 microelements examined were applied at four levels prior to the sowing of maize in spring 1991. The $13 \times 4=52$ treatments were set up in 2 replications on a total of 104 plots arranged in a split-plot design. The loads were $0,90,270$ and $810 \mathrm{~kg} / \mathrm{ha}$ for each element, applied in the form of $\mathrm{AlCl}_{3}, \mathrm{NaAsO}_{2}, \mathrm{BaCl}_{2}, \mathrm{CdSO}_{4}, \mathrm{~K}_{2} \mathrm{CrO}_{4}, \mathrm{CuSO}_{4}, \mathrm{HgCl}_{2}$, $\left(\mathrm{NH}_{4}\right)_{6} \mathrm{Mo}_{7} \mathrm{O}_{24}, \mathrm{NiSO}_{4}, \mathrm{~Pb}\left(\mathrm{NO}_{3}\right)_{2}, \mathrm{Na}_{2} \mathrm{SeO}_{3}, \mathrm{SrSO}_{4}$ and $\mathrm{ZnSO}_{4}$. The whole experiment was uniformly supplied with basic $\mathrm{N}-\mathrm{P}_{2} \mathrm{O}_{5}-\mathrm{K}_{2} \mathrm{O}(100-100-100 \mathrm{~kg} / \mathrm{ha})$ fertilizer in the form of ammonium nitrate, superphosphate and potassium chloride. The crop sequence was maize, carrots, potatoes and peas. The results of the beetroot experiment carried out in the $5^{\text {th }}$ year can be summarized as follows:

1. The contamination could only be partially detected by soil analyses, to a different extent for each element. After digestion with cc. $\mathrm{HNO}_{3}+$ cc. $\mathrm{H}_{2} \mathrm{O}_{2}$ over $90 \%$ of the $\mathrm{Pb}$, $\mathrm{Sr}$, Ba, $\mathrm{Ni}$ and $\mathrm{Zn}, 60-90 \%$ of the $\mathrm{Cu}, \mathrm{Se}, \mathrm{As}$ and $\mathrm{Hg}$, and $30-60 \%$ of the $\mathrm{Cr}, \mathrm{Cd}$ and Mo could be detected in the ploughed layer. The $\mathrm{NH}_{4}$-acetate + EDTA-soluble fraction was found to contain over $90 \%$ of the $\mathrm{Pb}, 60-90 \%$ of the $\mathrm{Sr}, 30-60 \%$ of the $\mathrm{Cu}, \mathrm{Zn}, \mathrm{Cd}$, $\mathrm{Ni}$ and $\mathrm{Se}, 10-30 \%$ of the As, Ba, Mo and $\mathrm{Hg}$, and less than $10 \%$ of the $\mathrm{Cr}$. The accumulation of Al could not be detected with either method. Further studies will be required to determine the sources of the losses (adsorption, leaching, evaporation, uptake).

2. Of the 13 elements examined, $\mathrm{As}, \mathrm{Cd}, \mathrm{Cr}$ and Se proved to be toxic to beetroot. In this dry year the crop produced a beet yield of 15-20 t/ha on untreated soil, which was reduced to $1.5 \mathrm{t} / \mathrm{ha}$ at the maximum $\mathrm{Cd}$ level and to $3.5 \mathrm{t} / \mathrm{ha}$ at the highest $\mathrm{Cr}$ rate. The application of 270 or $810 \mathrm{~kg} / \mathrm{ha}$ Se five years before led to the complete destruction of both the beetroot and the weeds. The negative effect of As loads did not affect the beet yield at harvest.

3. The maximum concentrations of the elements were generally found in the leaves at harvest, but similar contents were also observed in the roots. The contents of As, $\mathrm{Cd}$, $\mathrm{Hg}$, Mo and Se in the plant organs were 2-3 orders of magnitude greater than in the control, while the increase in the concentration of $\mathrm{Ba}, \mathrm{Cu}, \mathrm{Sr}$ and $\mathrm{Zn}$ was more moder-
\end{abstract}


ate, the values being several times that of the control. On average the $\mathrm{Cr}, \mathrm{Ni}$ and $\mathrm{Pb}$ contents increased by an order of magnitude on heavily contaminated soil.

4. The specific element requirements of $10 \mathrm{t}$ beets + the relevant foliage were as follows: $44 \mathrm{~kg} \mathrm{~N}, 6 \mathrm{~kg} \mathrm{P}\left(14 \mathrm{~kg} \mathrm{P}_{2} \mathrm{O}_{5}\right), 56 \mathrm{~kg} \mathrm{~K}\left(67 \mathrm{~kg} \mathrm{~K}_{2} \mathrm{O}\right), 25 \mathrm{~kg} \mathrm{Ca}$ and $18 \mathrm{~kg} \mathrm{Mg}$. The extremely high specific $\mathrm{N}$ content can be attributed to the dry year. These data could be used as guidelines by the extension service.

5. On contaminated soil the maximum element uptake (roots + foliage at harvest) amounted to $1600 \mathrm{~g} \mathrm{Sr}, 1200 \mathrm{~g} \mathrm{Mo}, 800 \mathrm{~g} \mathrm{Se}, 360 \mathrm{~g} \mathrm{Zn}, 240 \mathrm{~g} \mathrm{Ba}, 80 \mathrm{~g} \mathrm{Cd}, 70 \mathrm{~g} \mathrm{Cu}, 50$ $\mathrm{g} \mathrm{Cr}$ and $\mathrm{Ni}, 40 \mathrm{~g}$ As and $\mathrm{Hg}$, and $24 \mathrm{~g} \mathrm{~Pb}$ per hectare. On heavily loaded soils phytoremediation is not a real answer to the problem. Even if the yield of beetroot, which is capable of intensive element accumulation, could be increased by an order of magnitude (to achieve a Cd uptake of $800 \mathrm{~g} / \mathrm{ha} / \mathrm{year}$ ) a thousand years would be required to clean the soil.

Table 1. Agronomic measures and observations (Calcareous chernozem soil, Nagyhörcsök, 1995). (1) Agronomic measures. (2) Date (year, month, day). (3) Note. 1. Autumn NPK fertilization - applied by hand per plot. 2. One-way ploughing - MTZ 80 + Lajta plough. 3. Harrowing - MTZ $50+$ Lajta harrow. 4. Spring application of N fertilizer - applied by hand per plot. 5. Combined soil cultivation - MTZ 80. 6. Sowing, rolling - individual seeds, with a drill. 7. Staking out of the experiment - manual placement of stakes in each plot. 8. Scoring for weed cover - on a 1-5 scale for each plot. 9. Scoring for plant development - on a 1-5 scale for each plot. 10. Hoeing to control weeds - in the whole experiment. 11. Hoeing to control weeds - in the whole experiment. 12. Plant sampling -20 shoots/plot. 13. Plant density adjustment - manually for each plot. 14. Plant sampling -20 leafy beets/plot. 15 . Scoring for plant development - on a 1-5 scale for each plot. 16. Harvesting - on 24 running metres per plot.

Table 2. Monthly, quarterly, annual and vegetation period precipitation sums, $\mathrm{mm}$ (Calcareous chernozem soil, Nagyhörcsök, 1995-2000). (1) Months a)-1) JanuaryDecember; m)-p) $1^{\text {st }}-4^{\text {th }}$ quarters; r) annual sum; s) monthly, Apr.-Sept.; t) monthly, Oct.-Jun. (2) Mean. Note: the many years' mean was the 50-year mean measured at the closest meteorological station in Sárbogárd.

Table 3. Effect of treatments on the composition of the ploughed layer, $\mathrm{mg} / \mathrm{kg}$ (Calcareous chernozem soil, Nagyhörcsök). (1) Element. (2) Loads in spring 1991, $\mathrm{kg} /$ ha. (3) $\mathrm{LSD}_{5 \%}$. (4) Mean. A. Digestion with cc. $\mathrm{HNO}_{3}+\mathrm{cc}$. $\mathrm{H}_{2} \mathrm{O}_{2}$. B. Digestion with $\mathrm{NH}_{4}$-acetate + EDTA in 1994.

Table 4. Effect of toxic elements causing yield reductions in beetroot (Calcareous chernozem soil, Nagyhörcsök, 1995). (1)-(4): see Table 3. A. Scoring for plant development, May $29^{\text {th }}$. B. Scoring for plant development, Sep. $11^{\text {th }}$. C. Fresh foliage mass, $\mathrm{g} / 20$ plants, Jun. $21^{\text {st }}$. D. Fresh foliage mass, t/ha, Sep. $11^{\text {th }}$. E. Fresh root mass, t/ha, Sep. $11^{\text {th }}$. Note: air-dry matter in the foliage on Jun. $21^{\text {st }}: 9 \%$, at harvest: $18 \%(14 \%$ in the roots on average). Scoring: 1: very weak, dying stand, 5: well-developed stand.

Table 5. Effect of toxic elements causing yield reductions on the development of beetroot and weeds, May $31^{\text {st }} 1995$ (Calcareous chernozem soil, Nagyhörcsök). (1)-(4): see Table 3. A. \% beetroot cover. B. \% weed cover. C. Total \% cover. D. $\%$ cover with 
Amaranthus blitoides. Note: In addition to 3-4\% cover with Chenopodium species, a further 13 weed species were identified.

Table 6. Effect of treatments on the element content of air-dry beetroot (Calcareous chernozem soil, Nagyhörcsök, 1995). (1) Plant organ. a) leaf ${ }^{1}$, b) leaf ${ }^{2}$, c) $\operatorname{root}^{2}$. (2)-(4): see Table 3. A-L. As the result of As, $\mathrm{Ba}, \mathrm{Cd}, \mathrm{Cr}, \mathrm{Cu}, \mathrm{Hg}, \mathrm{Mo}, \mathrm{Ni}, \mathrm{Pb}, \mathrm{Se}, \mathrm{Sr}$ and $\mathrm{Zn}$ loads, respectively, $\mathrm{mg} / \mathrm{kg} .{ }^{1}:$ in the middle of the vegetation period, on Jun. $21^{\text {st }} 1995$; ${ }^{2}$ : at harvest, on Sep. $7^{\text {th }} 1995$. Note: The As and $\mathrm{Hg}$ contents were below $0.1 \mathrm{mg} / \mathrm{kg}$ on untreated soil.

Table 7. Effect of treatments on the $\mathrm{NO}_{3}-\mathrm{N}$ content of air-dry beetroot (Calcareous chernozem soil, Nagyhörcsök, 1995). (1)-(4): see Table 3. A. In the leaf on Jun. $21^{\text {st }}$, $\mathrm{mg} / \mathrm{g}$. B. In the root on Sep. $7^{\text {th }}, \mathrm{mg} / \mathrm{g}$.

Table 8. Mean element contents of air-dry beetroot on untreated soil (Calcareous chernozem soil, Nagyhörcsök, 1995). (1) Element. (2) Units. (3) Leaf on Jun. $21^{\text {st }}$ and Sep. $7^{\text {th }}$. (4) Root on Sep. $11^{\text {th }}$. Note: As, $\mathrm{Hg}$ and Mo below $0.1 \mathrm{mg} / \mathrm{kg}$. The air-dry matter content averaged $9 \%$ on Jun. $21^{\text {st }}$ and $18 \%$ on Sep. $7^{\text {th }}$ in the leaves and $14 \%$ on Sep. $11^{\text {th }}$ in the roots.

Table 9. Mean and specific (10 $\mathrm{t}$ fresh beet at harvest + the relevant foliage) element uptake of beetroot on untreated soil (Calcareous chernozem soil, Nagyhörcsök, 1995). (1)-(2): see Table 8. (3) Element uptake at harvest. (4) Foliage. (5) Roots. (6) Total. (7) Specific element uptake, $\mathrm{kg} / 10$ t. Note: the As, $\mathrm{Hg}$ and Mo uptake was below the measurement limit. Maximum uptake on contaminated soil: Sr 1600, Mo 1200, Se 800, Zn 360, Ba 240, Cd 80, Cu 70, Cr and Ni 50, As and $\mathrm{Hg}$ 40, $\mathrm{Pb} 24$ g/ha. 